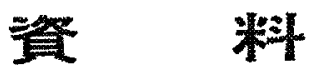

\title{
わが国の遮蔽研究の現 状
}

\author{
遮蔽研究専門委員会の報告
}

\author{
遮蔽研究専閒委員会*

\section{Some Topis from Activities of Special Committee on Radiation Shielding in Japan}

By Special Committee on Radiation Shielding

\begin{abstract}
A summary is given on the activities of the "Special Committee on Radiation Shielding" in the two years from its establishment in May 1964 to its dissolution in March 1966. The review covers the past and present status of studies undertaken and problems that remain to be done.
\end{abstract}

\section{まえがき}

1964年 5 月に発足した遮蔽研究專門委員会(以下本 委員会と称する)は，本年(1966年) 3 月をるって終了 した。この間16回の会合を持ち，委員掊よび参加者に 上る熱心な討論が行なわれた。これらの討論の概要を 報告し，今後の研究活動の資料とするため本稿を起草 した。

本委員会で討議された主題は，(1)諸外国の研究の現 状調查と検討，(2)各論，(3)加が国の最近の研究の成果 と展望, の 3 部に大別される。

第 1 部では本委員会の発足時に前後して遮蔽研究者 にとり極めて重要な 2 つ国際会議一原子炉遮蔽心 ネル会議(ウィーン (1) 扰上び第 3 回原子力平和利用国 際会議(シュネープ)—が開催された。前者に提出さ れた各国の論文を 3 回にわたり，後者に提出された各 国の論文を 2 回にわたり討論した。これらの論文に表 われた各国の遮蔽研究の現状については，それぞれの 担当者が取りまとめ。原子力工業誌上に特集として 揭載された(2)。高速炉開発がかが国 の原子力開発の重 要なテーマになりつつあることから，各国の高速炬遮 蔽の現状を議題とした。その際の調算討論を中心とし て，担当した委員が取りまとめ，『原子力工業誌上比 特集として揭載された(28)。

第2部の，本委員会で討議された各論的なテーマの主 なすのは，つぎのと打りである。(1) $\gamma$ 線の多重層透 過，(2)多重層中の高速扰よび熱中性子束分布，(3)捕獲 $\gamma$
線とその遮蔽，(4)遮蔽研究に扣ける計測の問題，(5)原子 力船遮蔽モックアップ実験計画, (6)加速器の遮荋, (7) 2 次诺蔽の問題点（8)フルベド，スカイシャインに関する 問題点, (9)ダクトストリーミング。

これらのテーマのうち，一部はすでに個人名で総説 またはショートノートとして本「会誌」上に揭載された むのもあり，揭載学予定されているすのすある(3)(6)。

折上く本学会门昭和 41 年年会」(1966年 3 月)において 遮蔽研究関係の総合講演を行な5機会を与えられた。 本委員会のしめくくりとして，われわれの活動の反省 と展望を行ならため，小委員会**を構成し，数度の会 合を行ない，総合講演原稿の起草を行なった。2 回の 委員会の検討を経て田中委員が総合諥演を行ない，加 つ誌上揭载可能の体裁をととのえた原稿を作製した。 本報告書はこの講演のために起草された原稿に加筆編 集を行なったるのである。

*（主查）兵藤知典，

(幹事) 大島正幸, 中田正也, 新藤满夫

（委員）阿部進, 梅田賋, 大野博教, 岡島啺夫, 片阙筑、金森善彦，北爪光幸，島村光，

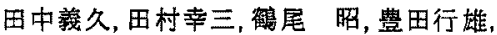
永原照明，八谷雅典，布施卓害，古田悠， 宮坂酸一, 矢島 明, 八巻秀婎

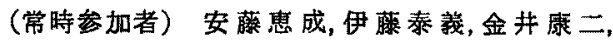
河野 汀，竹内 清，播缕良子，東原義治， 丸山隆司，宮越淳一，山路和堆，古川芳德， 山本守之, 森 㫕一

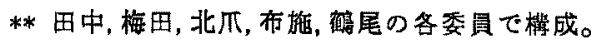




\section{I . 遮蔽研究の問題点}

「放射楾遮蔽」とはい亦京る学問であううか。歷史的 にみれば，対象とする放射線源によって，あるいは関 連分野の発展により，中心課題はかなりの変化をして いる。現在のかか国では，原子力産業の発展に貢献す る原子核(力)工学の一分野として，遮蔽研究を正しい 方向に推進する必要がある。

歴史的に見ると、アメリカ，イギリス、ソビェト等で る初期の研究用原子炉の遮蔽は必要な設計データが不 充分だったので，必要以上の厚さの遮蔽体を用い，もし 不足の場合はコンクリートブロック等の補充を行なら ことで解決した。アメリカのオークリッシで，骕蔽研 究の目的で Lid Tank Shielding Facility およびBulk Shielding Facility が建設された頃から，各国で熱心 に遮蔽研究が開始された。これは高出力, 高中性子密 度の実験炉や動力炉の実用期に入り，間に合わせ的な 遮蔽では建造費がかさむこと，宇宙開発き原子力船の 建造には遮䖍が最す重要な要因の 1 つなることなど の外的要因と，中性子扰よび $\gamma$ 線の物質中の挙動に関 する研究が進み，必要な線源と計算機が使用可能とな って来たことの内的要因により，1つの分野が出来た るのと考えられる。

遮蔽研究には，現在どのようなテーマが取り上げら れ、また将来取り上げられるべきであるうか。簡単に 遮蔽研究全体のサーペイをしてみ上う。研究の範围を 明確に分けることは困難であるが，

（1）中性子扣よびみ線と物質との相互作用に関する 物理学々之の応用の分野——基整研究

(2) 原子力開発研究の分野——開発研究

の 2 つ大別してみる。現在最も重点が初れて研究 されているテーマは，多くの場合この両者関するの で項を改めて列挙する。もちろん遮椟研究の体制にす 重要な問題があるが，この点については本報告書の最 後で考えてみることにする。

\section{1. 基磷研究}

基礎研究の中心課題は，比較的簡単な幾何学的条件 の下に物質中で放射線がいかに減少するかという問題 である。

多くの場合，原子师遮蔽を対象々するから，放射線 は中性子と $\gamma$ 線である。人工衛星宇宙船等の設計に は，高エネルギー陽子，電子す対象となることがめる。 また高エネルギー加速器であれば，その加速された柆 子括上び 2 次放射線 ( $100 \mathrm{MeV}$ 程度の中性子が多い) が対象となる。本委員会では，電子線型加速器の遮蔽
を1回取り上げた忹か虫，対象とする放射線はすずて 中性子と線であった。

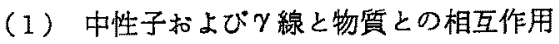

中性子扣よび $\gamma$ 線と物質との個々の相互作用につい， ては，過去数十年間に核物理学の中心課題の1つとし て取り上げられたことがあり，かなりのデータが集積 されている。これらは，われわれの観点からいえばミク ロなデータとして非常に重要である。最るデータの不 足しているのは中性子の非弾性散乱である。の反応 は原子番号の大である物質に対し非常に重要な役割を する。

（2）マクロな諸定数

われわれが対象とする厚い物質壁の中性子や7線の 透過ては，多重散乱が行なわれる。すなわち、マクロ な立場で現象を見なければならない。われわれの分野 で重要な役割を占めるのは， $\gamma$ 線の物質透過に関する マクロな定数である質量減衰保数およびビルドフップ 率,アルベド,中性子の除去断面積, 減速拡散の組定数 である。

質量減衰係数は，われわれの使用に充分な精度で求 められ(778)，実験とる非常によく一致している。モー メント法により無限媒質に対する物質中の $\gamma$ 線のスペ クトルおよびビルドアップ率が Goldstein ら界によっ て計算された。このデータは現在に至るる非常に有用 である。有限な厚さの物質に対するビルドアップ率 は，モンテカルロ法および実験により決定されたが， 充分ではない。

高速中性子の透過に関する除去断面積はすでに多く の物質に対し，実験仙より求められている。最近物質中 の中性子スペクトルの測定淤行なわれるよ5になり， エネルギー群ごとの減弱距離も測定されるようになっ た。

(3) 計 算 法

中性子および $\gamma$ 線の物質透過の現象を理論的に記述 し，データを求める方法には，ボルッマンの方程式を 解く方法、除去一拡散法、モンテカルロ法、レスポンス行 列法が早くから行なわれている。

a. ボルッマンの輸送方程式

中性子怙よび $\gamma$ 線のマクロな物質透過恃ボルッマン の輸送方程式で表わすことができる。断面積その他の 基整定数が知られており，必要な境界条件でボルッマ ンの輸送方程式の解を求めることができれば問題はな いのであるが，簡単に解が得られない。このため簡単 な幾何学的条件に対し，モーメント法その他の近似解 を得る方法が開発された。そのうちで無限均一媒質中 


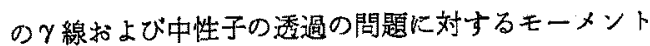
法の適用は非常な成果をあげ，その計算結果は現在で す非常に有用なデータとして使用されている。

最近各国でボルッマンの輸送方程式の厳密解を計算 するコードの開発積極的に行なわれている。

b. モンテカルロ法

中性子扣よび あるので，モンテカルロ法の適用が可能である。 の後方散乱の問題はモンテカルロ法の適用の最も成功 した例の1つである。 透過に対しては，良好の結果を得た。これらのデータ は現在です非常に有用である。深い透過，ダクトスト リーミング等の問題に関しては，そのままでは必ずし 充分な精度が得られていない。

\section{c. 除去一拡散法}

線源から放出された高速中性子の最初の衝突までを 除去断面積を用いた指数関数的な減衰とし，以後を多 群拡散方程式を用いて物質中の中性子分布を求める除 去一拡散法か遮蔽設計計算法として，かなりの成功を おさめている。

\section{d. その他の計算方法}

モーメント法,モンテカルロ法, 除去一拡散法以外に 6、レスポンス行列法, invariant imbe dding 法等の 適用が成果をあげている。

(4) 線源

小は $1 \mathrm{mCi}$ 以下の $\gamma$ 楾密封楾源から，大は原子师に 至る種々の線源が用いられる。代表的なるのは点等方 楾源, 点一方向線源(コリメートされたビーム), Lid Tank Shielding Facility，水泳プール型原子炉などが 多く使用されて来た。今後も実験でこれらの線源を 専ら使用すると共に，線型加速器のよ 5 な高出力線源 等も必要とすることがあろ5。逆に低出力でっても 单色の中性子等を必要とすることすあるでから5。ま た，原子炉および加速器によるパルス中性子必必要と するであろ5。

(5) 測 定器

実駿を行なら場合の測定器は，ほとんど全部が核物 理用および保健物理用として開発されたるのである。 遮蔽研究で測定するのは中性子および $\gamma$ 楾で 2 次放射 線を計湘すること，線末束または線量が非常に強い所か ら非常に弱い所まであること、いままでの多くの測定 は線鯉分布であったが今後はスペクトル空間分布の測 定す要求されるであろ 5ことなどから，かなりシビヤ 一な条件の下炕ある(3)。いままでの測定には電離箱， 放射化法，化学線量計，G.Mカウンタ，BF 3 カウンタ，シ
ソチレーションカウンタ，写真フィルムなどが多く用 いられたが，今後、半導体カウンタ，ガラス線量計など る大いに活用されるであるう。

（6）計算結果と実娩結果との対比

実験および計算は，てれ自身独立したデータを得る ために行なわれることもあるが，初めから他を意識し て相互の対比をし，計算データ，入力データ，測定器 の特性の妥当性をチェックすることがよく行なわれ る。この場合，両者て探用した幾何学的条件が異なっ ている場合は幾何学的に，むるいは減衰核法などで変 換が行なわれる。

\section{2. 開 発研 究}

原子力工業の発達, 原子炡の開発の進展は日進月歩 である。遮蔽設計においてる過去の経験を充分生かす と共に，基礎研究，関連分野の研究成果を䋓え寸注目 して設計に取り人れて行くことが必要である。また， 開発研究では，経済性が重要な要素の1つとなる。

放射線の物質中の挙動は，その物翼に固有なるので あって，適当な資料の選択による小型化した模型実験 を行ならことは不可能である。したがって，実物の原

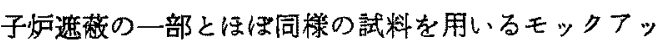
プテストも必要となる。

（1）原子炉遮蔽設計上の問題

遮蔽を設計上から考えると放射線防護設計の1 分野 であり，機器構造設計，建設，安全性対策と密接な関係 にある。これら3つの関連分野の設計基準や設計方針 によって非常に影響を受け，ての大きさ，重量、コスト が大きく変わり，経済性に与える影翌は大きい。原子 力の経済性が問題になればなるほど，ての重要性は増 して来ている。

開発研究での設計は，わからないではすまされない のであって，对象としている原子焐の各設計段階に応 した計算と実験がその重要度中緊急度に従って計画さ れ，実施される。遮蔽設計においてもその例外ではな い。その計算と実験に遮蔽基礎研究の成果が反映され ると同時に，遮蔽研究の新しい対象を提供する毒体と るなっている。ここに，遮蔽設計法の改良と遮蔽研究 の促進とは相互に原因と結果となり，発展するるので ある。実際に自国で自主的に原子炉を開発している国 では，独自の遮蔽設計法と遮蔽理論を生み出している ことに注目しなければならない。

（2）近似計算法, 設計コードの開発

さらに，透蔽設計法においては，要求されるまらゆ る問題を必要とする䄇度で経済的に害施できるるので あることが必要であろ5。この点で基礎的な遮蔽研究 
の成果をその精度を失うことなく簡易計算法やグラフ 化等の経験法則化して扰くことが必要であり，さらに 原子炻設計の各段階(基本計画, 基本設計，詳細設計)て 要求される程度に応じた遮蔽設計法を開発しコード 化しておかなければならない。これらの近似計算法お よび設計コードの精度をチェックし，改良して行かね ばならない。

（3）遮萪設計に必要なデータの測定， 計算コードの集積

遮蔽設計に必要なデータは非常に膨大な量である。 速蔽に関する教科書，参考書，資料集すかなり出版され ているが(11) て(19)，これたけけで柱すべての資料を網羅し ているわけではないっメリカのオークリッシ国立研 究所K Radiation Shielding Information Center (RSI C)が 1963 年に設置された。わが国でも数個所の研究 譏関が登録し情報の交換を行なっている。RSICでは 各国の各研究機関で開発された計算コードの集積と共 にテストランも行ない，各コードの精度の比較検討を している。

(4) モックフップ・テスト

遮蔽の開発研究として久くことのできないすのにモ ックアップテストがある。例えば，水泳プール型原子 师を用いて実際の規模に近い遮蔽の一部を陚料とし て, 中性子と線の透過，ダクトストリーミング等の 実験を行ならものである。実際的な不規則形状の遮蔽 体に対する括蔽計算コードが確立していないので非常 に重要なことである。この上うな技衙的な問題は科学 論文としてまとめにくく，多くの場合は学会誌上には 揭載されない。各国では湖大なデータの量となってい ると思われるが，これかっらわが国の必要な資料を選规 すること虫不可能に近い。したがって，われわれは必 要とするモックフップ・テストを目らの手で行なわ权 ばならない。遮蔽設計か必要がある限りモックアッ プ・テストは必要であり，必要に匛じて直ちに実施で きるようにしておかねばならない。

\section{（5）遮蔽材料の研究}

遮蔽体を多重層にし，あるいは適当な混合物を用い ることにより，その物質の遮蔽体として有利な特街を 生かすことが重要である。コンクリートの骨材として 用いる場合には，その地方に産出する鉣石の故射線に 対する特性を充分知って括く必要がある。材料の選 択, 施工のいかんは原子炉施設の経済性に大きな影響 を与克る。その他，高温，故射線損侮に対する研究等 の他分野の基碳的な研究の成果学自由に駆使しなけれ ばならない。
（6）経済性の追求

建設費の節約とい5至上命令に対処した開発研究が 考えられる。

\section{a. 遮蔽体の建設费の最適設計}

より正確なデータを用いることにより安全係数を小 さくとる，種々の材料を組み合わせ，2次遮蔽を考える， 施工性を考える等，建設費をパラメータにとった最適 設計をする。

\section{b. 速蔽体重量の最適設計}

特に宇宙開発や原子力船では，㟟蔽の重量が価格に ひびいてくる。このため重量の減少が重要となり、こ の方面での最適設計を要求される。

c. プラント全体の経済性の追求の影響

原子力プラント全体の経済性の追求からも遮蔽設計 は大きな影響を受け，これに対応する開発研究が必要 となる。

3. 現在各国で行なわれつつある主な研究テーマ

各国で実施されている研究テーマは，これらの基礎 研究拉よび開発研究のいずれかの部分，むるいはこれ らの部分にまたがったすのが大部分である。

\section{（1）多重首透過}

高速中性子の吸収断面積は小であるので，大部分の 中性子は減速一吸収の過程をたと゚る。このためには原 子番号の小の物質か有利でる。他方 $\gamma$ 線に対しては， 密度の大の物質が楾減衰係数が大である。原子少のよ $5 に \gamma$ 線と中性子が共存する線源の透蔽には，これら の放射線に対して特性の異なった物質の多重層を用い ることが有利である。このため，こういった多重層の 線透過，中性子透過の問題加研究された。 $\gamma$ 線に対し ては，わが国およびソビェトでかなり重要な研究がな されて来た。

ケ線の多重層透過に関しては，片岡により総説が青 かれた(4)。中性子の物質透過についても本委員会での 討論の結果をまとめて，本「会誌」上に別に発表する予 定である。

（2）ダクトストリーミング

原子炉括蔽はダクトを有する場合が多い。このダク 卜を通って出て来る中性子拉よびy線は，遮蔽体を透

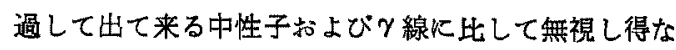
くなる。このためダクトストリーミングの研究が重要 となり, 理論的実験的な多くの研究が行なわれてい る。

中性子扰よびそ線は, 固·液層では減速吸収で大きく 隇衰するが、気層中ではほとんど距離的な隇衰だけに しか期待できないので，この固・液層中の一部に気層、 
すなかちダクトがあると，そこを通る放射線はその部 分て他と比較し淢衰が少ない。この最る一般的で典型 的なあのが，遮蔽体のダクト中で起るダクトストリー ミング現象であり，遮蔽体中の衭管問題として常に 遭遇する。最近のよ5に遮蔽体が一体化して来ると， 外面の放射線量がダクトからの洩れの量で規定される ようになって来るので, 澱蔽設計面からも重要性が増 して来た。物理的にはダクトストリーミングには3つ の成分がある。

(1) Direct component：線源がら直接ダクトを

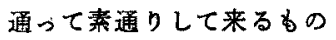

(2) Albedo component : 線源からーたんダクト 壁に入り反射されて出て来るるの

(3) Leakage component: 周辺の媒質からダク ト中に洩れ入ってそのまま出てくる。

(2)，(3)の成分はダクト中でさらに多重散乱される。

(3) 後方散乱

原子炉本体の遮蔽には，後方散乱はあまり考えなく てるよいが，ダクトストリーミングと深い関係を有し ている。船船, 照射, 菱置等の設計の場合には，後方散 乱を考えなければならない。 $\gamma$ 線の後方散乱の研究 は，わが国、アメリカ、ソビエト等で行なわれて来た。 今後もダクトストリーミング, 多重層透過等の関連に 招いて，来た遮蔽設計的な見地からす研究を続けるべ きであ万う。中性子の後方散乱に関してはあまり多く の研究がなされていない。 $\gamma$ 線の後方散乱に関しては 兵藤により総説が書かれた(6)。

(4) 捕獲 $\gamma$ 線とその遮蔽

数個の原子番号の小である元素を除き，中性子を原 子核が捕獲した場合には，捕獲 $\gamma$ 線を放出する。水素 等の特陎な元素除き，中性子結合エネルギーは6〜 $8 \mathrm{MeV}$ である。カスケードに転移が行なわれて数個 の $2 \sim 3 \mathrm{MeV}$ の $\gamma$ 線を故出する場合るあるが， $5 \sim$ $8 \mathrm{MeV}$ の高エネルギー $\gamma$ 線を放出する場合す多い。 したがって，中性子の遮蔽を考えるにあたっては，捕 獲 $\gamma$ 線に対する考虑が必要となる。逆に捕獾 $\gamma$ 線を推 定するには，遮蔽体を構成する物質と遮蔽体中での中 性子束分布を推定する必要がある。

（5） 2 次遮蔽

動力炉の遮蔽では，㣌心の遮蔽と熱交換器等の遮蔽 とを分離することによりコストを下げている場合が多 い。何を対象とし，どこに 2 次逅榙を固くべかは，基 碄研究での種々のデータおよび計算法で推察しなけれ ばならない。

(6) スカイシャイン
大型原子师怙よび大型加速器では，上方に抜けた放 射線が空気中の原子の散乱に上り施設外の線量に影響 を与皇る。が国の上5に人口稒密な地区の多い国で は，敷地の選定にからみ特に問題が多!、たあ万弓。

(7) 不規則形状への対策

多くの場合，基礶データが得られた幾何学的条件と は異なった条件で設計が行なわれる。このためどの上 らにデータ補正を加えるか等に対し，研究が必要であ るが、あまり多くのデータは発表されていない。

\section{II . 本委員会設置以前のわが国の 遮蔽研究の概要}

わが国に括いて遮蔽研究がどの上うに行なかれて来 たかについては 2,3の文献があるが(20)(21)，間単に心 り返ってみよう。

わが国の遮蔽研究者がこの分野の研究にたずさわる に至った動機は種々である。原子少，原子力船の設計 にたずさわった者，特にこの分野に関心をるっている 研究機関，会社等に所属する者，放射線と物質との相 互作用に関心を当ち，物理学と工学との中間領域とし てこの分野に関心をもった者等である。

石川らにより国産 1 号炉(JRR-3)の設計計算がなさ れだ当初は，電子計算機の使用が不可能であり，計算 法るデータすすべて外国のるのによっていた (22)。

かが国火電子計算機が導入されて以来，遮蔽計算コ 一ド対する研究者の関心が强まり，原子力船の建造 計画の具体化によりさらに強まった。本学会に「計算二 ード専門委員会」が設置され，しばしば遮蔽計算コード が取り上げられた。日本原子力船研究協会でる遮蔽研 究を強力に取り上げるに至った。RACコード等の自 主的な遮蔽計算コードの開発, 外国コードの消化が,こ れらに参加した人々を中心に行なわれた (23) 〜25)。

かが国では原子炉の建設がフメリカ,イギリス,ンビ エト等より逯れたため，遮蔽の実験的研究は，主とし て $\boldsymbol{\gamma}$ 線の透過散乱について行なわれ，かなりの成果を あげた。中性子の物質透過の実験的研究は，本委員会 の発足とほほ同じ時期に出発した。また原子力船の遮 蔽設計のため、データの広籍囲なサ一べイおよび JRR -4の設計が行なわれた(25)〜(27)。

本委員会が発足する以前に行なわれた，理諭的抋上 び実験的研究をテーマ别に分類すると，つぎのよ5に なる。
(1) 計算コードの開発
（2） $\gamma$ 楾の多重層透過
(3) $\gamma$ 楾の後方散乱 
（4）中性子の多重層透過

(5) ダクトストリーミング

（6）不規則形状物効果

(7) 計測

(8) その他の問題

これらの研究テーマのかなりの部分は，本委員会発 足娞も引き続き実施されている。本学会の「年会」およ び分科会」た扎いて，「遮蔽」が部門として独立したの は「昭和38年年会」からである。それ以前にる多くの研 究発表が行なわれたが，残念ながら他の部門の一部に 含められていた。

\section{I．わが国の遮蔽研究の成果}

わが国り遮政研究は，不充分な設備，環境のもとで， 最大限の成果を挙げるべく研究者達が精力的な努力を してきた。ここでは，その貝体的な成果はどのような 形で現われたかを見てみ上5。

基碳定数がはっきりしていること，実験が比較的容 易にできること、計算時間もあまりとらないことから， わが国の遮蔽研究は，まず $\gamma$ 線の透過，散乱の基礎的 な問題ヒ大きな成果を挙げた。多重層透過と後方散乱 の問题点を理論, 実験的両面から解明することに集 中し，さらに複雑な形状(ダクト，不規則形状物)の透 過散乱問題へと進んでいる。

研究用原子少の利用，すなわら中性子線源が利用で きる:つれて、中性子の多重層，ダクトストリーミング の研究が始京り，徐々に成果を挙げつつあるが，まだそ の緒についたはかりであり，中性子楾源利用の一般化 に伴ってこの面での研究は今後大きく進展しよ5とし ている。さらに, 原子力第 1 船建造に伴 5 遮蔽研究開発 が新しい砳究体制で組縕的に開始された。

\section{1. $r$ 線の物澌透過}

数年前遮蔽設計時に多重層透過のビルドフップ率を ど 5 評価するかとい 5 問題が提起された。当時教科書 では，各層のビルドアップ率の積といら形で評価して いたが、これは非常に過大評俩になることが指摘され た。一方フメリカでは，モンテカルロ法による計算に より多重層のビルドアップ率が，重い物質，軽い物質の 組合世順序でかなり差があらわれることが雌認され， Kalos の半経験式の形に整理された。ソビエトでは， 放射性同位元素による系統的な多重層組合女実験を行 ない, 多重層透過ビルドアッブ係数の Broder の実験 式の形に整理された。わが国においてる，ほとんど同 じ頃に実験が言画され開始された。問題になったの は、つぎのと放りである。
(1) 実 験

a. 原子番号の小である物質の後に原子番号の大 である物質を置いた場合とその逆の場合とでは，両媒

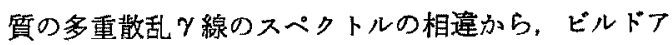
ップ率の変化が当然起る。これを測定により確認し， 実験式を求めた。現在までに行なわれた研究を参考文 献28) (35)に示す

(2) 計 算

基本的な計算コードが各研究者により整備されると 共に, 応答マトリックス法, 近似計算法, Invariant Inbedding 法などによる計算が試みられた。わが国で開 発された $\gamma$ 線の物質透過計算コードを参考文献(36) ( 43 ) に示す。

\section{今後に殘されている問題点}

（1）多重層物質中の多重散乱 $\gamma$ 線のスペクトルと 角度分布を正しく評価すること。

(2) 10 m.f.p. 以上の厚い透過 ( 20 m.f.p. 程度 まで和よび高エネルギー領域 $\gamma$ 線の多重層ビ ルドアップ率の実験湘定执よび理論計算の実施 と経験式化すること。

（3）実験，計算対象を実用な物質全般に拡大寸る こと。

2. $\boldsymbol{r}$ 線の後方散乱

有限または半無限大物質，または真空の境界面に接 して他物質がある場合，他物質により散乱された $\gamma$ 線 が交たその物質に入射して来る現象である。

わが国でる，後方散乱線のエネルギー・スペクト ル，角度分布の測定より，锁分アルベド,アルヘドが測 定された。この結果はよくモンテカル口計算拈よび invariant imbedding 法によ方計算と一致している。 わが国における $\gamma$ 線の後方散乱の研究を参考文献(44) (50)に示す。

今後に残されている問題点

(1) ある場所への入射 $\gamma$ 線が他の場所から出て来 る場合のエネルギー角度分布を明らかにするこ と。これはタ゚クトストリーミングへの応用の場 合に重要である。

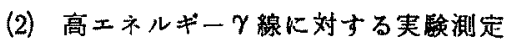

（3）有限層, 梁い㬝の 2,3 層からの後方散乱 $\gamma$ 線 の湘定, 計算

\section{3. 中性子の物筫透過問題}

わが国では，末ずフメリカ,イギリス両国の中性子 透過の理諭の消化とこれのコード化から始まった。除 去理論と拡散理論との組合せによるイギリス RASH コードを手本にし，18群の高速中性子除去領域とその 
おのおのに直結する拡散領域 6 群中性子減衰，炉心か

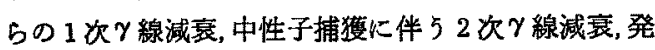
熱の4つを1つに組み合わせて RACンード(23)を開 発した。この RAC コードは多くの遮蔽設計計算に利 用されている。2，3年前加ら中性子線源の利用が各所 で出来るようになるにつれて，この RACコード計算 と実験との比較検討が開始され，計算，実験両面に多 くの問題が提出された。やっとこの面で信頼の扎ける RAC コードの完成へと第 1 歩がふみ出されたといた よう。はかにボルッマン方程式を敛密に解くコードす 作られつつある。報告された春験を参考文献51 ～(55) に、計算を(50，57)に示す

今後に残されている問題点

(1) RAC コードの徹底的な検討

\section{基整定数の暴定}

深透逼問題への適用(線量, フラックスの減 衰特性)

非含水索物質への適用(熱外中性子東)

（2）连蔽体洩九中性子のエネルギー角度分布

（3）熱外中性子捕獾 $\gamma$ 線, 非弾性 $\gamma$ 線評価

(4) 敏密解法の研究

（5）近似計算法の開発

（6）舶用炉，新型檕换炉，高速炉措蔽全般への適用

4. ダクトストリーミングの問題

わが国ての最近の研究す，むる程度第I章で述へたた 方向に沿ってなされている。 $\gamma$ 線のストリーミングに ついてはモンテカルロ法, 多重散乱法による倣密な取 报いが実施され，ダクト壁各部から反射する $\gamma$ 線の山

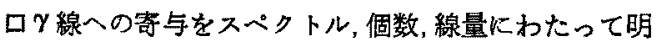
らかにし，生た， ${ }^{60} \mathrm{Co},{ }^{137} \mathrm{Cs}$ 線源による実測と比較 し，良好な結果を得ている。中性子についてはリドタ ソク学使用して水中の各種試料の中空パイプ中の速中 性子、熱外中性子, 熱中性子を測定し, 興味深い, 結果を 得ている。

参考文献 58 165)にこれらの研究を示す。

今後に残されている問題点

（1）フルベド，洩れ放射線等エネルギ一角度分布 の基整現象の解明

（2）年龄，拡散理論の適用モデル等近似計算法の 開発

(3) 瘚密解法の促進

（4）遮蔽体およびダクトの䙓雜なるのに対して実 魜データの蕃積と半経験式の導出

5. 計測の問題

栝蔽に関する計測には，多くの場合線量測定が行な
われてきた。これは同一測定器て測定しうる楾量の籍 井が大であること、設計の基準となる数值の単位が remで表わされることが多い等の原因による。最近こ の方面の研究が進歩するに従い，物体中の中性子， $\gamma$ 線のスペクトルおよび角度分布を知る必要も起って来 た。

特殊な測定，容易な幾何学的条件で測定したデータ をより一般的な幾何学的条件にするために，幾何学的 条件の交換が行なわれる。このため，しばしばけ線用 として長い円筒状電離箱が用いられた ${ }^{(66)(67) 。 ~}$

入射 $\gamma$ 楾が単色であって子，透過 $\gamma$ 線のちち多重散 乱 $\gamma$ 線は連続スペクトルをなす。 $\mathrm{NaI}(\mathrm{TI})$ シンチレー タで連続スペクトル $\gamma$ 線を測定するには，波高分布か らエネルギー分布への変換を必要とする。わが国でる いくつかの大きさについて、、、スポンス行列が求めら

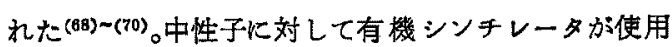
可能である。物質中の中性子のスペクトル空間分布の 測定に対してソビエトに括いて現在使用されている が，かが国です準備が完了して測定が開始された。

有機シンチレータでク線線量の测定をする場合，パ ルス波高にパルス数を掛けた量の集計が必要である。 これに対し非常に便利な測定回路が開発された(71)。

今後に残されている問題点

(1) 湘定器の充実

(2) 新しい測定器, 测定法の開発

（3）他分野で使用している測定器の導入，習熟

6. 線源の問題

(1) 体積線源

最近まで体積線源の計算を容易にするため，等価平 面線源を考えていた。これを計算容易な球款, 円柱と 圆換することで計算が容易心なった ${ }^{(72)(78) 。 ~}$

（2）水中に打ける光中性子束行布

炉心周辺の水中に括ける光中性子束の計算が行なわ れた(74)。

7. 開発研

わが国の開発研究は比較的少ない。これは JRR-4 が完成後間がないこと、開発研究は比較的論文になり にくいことなどが原因であると考えられる。

これらの分野の問題の取扱いはにとんど現象的な取 报い方に頼っているが，今後原子力船内の放射線可布 や最近のプラント一体化構造の傾向により，その重要 性は增加して来るであろ5。また，簡易な形状配置の るのについては，近似計算法あるいはモンテカルロ法 等砟密解法の試みる必要になって来ると考える。 この方面では，船舶技研の MARINE コードの開 


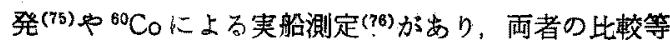
も行なわれているが，興味ある闍題も提起されており 今後の展開に期待したい。束た JRR-4による原子力

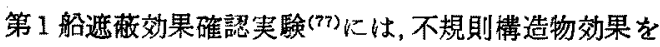
調べるモックアップテストす数多く含ましている。

金属管壁を透過する 皆無であったので，種々の厚さの鋼管についてビルド フップ率が測定された ${ }^{(78)}$ 。

狭い届曲したスリットからのストリーミングは、過 去に多少のデータがあるが，種ムの条件で測定が行な われた(70)。

スカイシャインの計算法 ${ }^{(80)}$ や遮枚体周辺線量分布 計算法 ${ }^{(81)}$ の開発も試欢られている。

今後に残されている問題点

(1) 設計計算用コードの開発

（2）遮蔽材料の放射線拉よび熱に対する研究

(3) 施工法に関する問題

(4) 経済性を含めた最適設計

（5）不規則形状物の遮蔽效果

\section{IV. 遮蔽研究体制の問題}

原子力の先進国では，国家の指導の下に原子力開発 体制が整えられ，政府出費の研究㙨閣が中心となっ て、遮蔽の研究，開発が進められている。いますてのわ が国の遮蔽研究は，国家の一貫したプロシェクトがな く，多くは大学，研究所，民間会社の自主的な研究にま かされていた。したがって，研究は小予算ででき， かるある程度この面ての成果を期待できる基脴的な研 究テーマにならざるを得なかった。

今後の研究の進め方について，2,3 の重要な問題に いて考竞，簡単に記してみることにする。

\section{1. 設備の問題}

放射性同位元素の利用が一般化し，その入手は容易 となり, 測定器等は安全なるのが得られるようになっ た。電子計算機の利用与一般化 L, IBM 7090,IBM 7044,CDC 3600, その他国産の高速計算機の使用子可 能となった。原子怔す各所に建录され，日本原子力研 究所では JRR-4が完成した。

これらを有效に利用すれば，かなりの成果がをげ得 よう。しかし，計算試料の製作，測定器の整㒉等には かなりの費用を要する。この上5な経済的予算を充分 に得なければ、これらの装置の充分な活用心望み得な W.

2.人の問題

いままです原子力船研究協会，引続き原子力船開発
事業団, 原子力産業会議等で遮蔽研究者の多くが集ま ることがあったが，広く全国的な視野の下に人が集ま る本委員会が設置されたことは誠に喜ばしいことて あった。

実際の研究に関しても，今後むますます人の交流を 盛んにし，前述の充分な研究費の裹付けを得て，設備 と人材の有効な利用を考えなければならない。るな新 しいこの分野に進む人々を受け入れる余裕を持つこと を関係方面に期待したい。

\section{3. 関連分野との提携}

遮薜研究，開発には多くの関連分野がある。この関 連分野との中間にもしギャップがあればこれを理め， より広い視野で研究を進めるべきである。またこれ らの関連分野の研究成果を速やかに取り入れ，重複を 避け，おのおのの研究の新たな発展のために活用すべ きである。

\section{V. 結語}

この報告の 1 連の考察からいえることは，

（1）今後行なわれねばならない遮蔽研究の課題は， 基礎研究, 開発研究と数多くめる。

(2) 新しい原子师の開発は新しい問题を提携し， 研究安剌激可方。

（3）計算では電子計算機,実験ては測定設備,測定 機器の進歩，充実を必要上する。

（4）実験师，原型师は，わが国の現状はすべて遮蔽 開発研究の対象であり，研究者が経験を持つ絶 好の機会である。

(5) 研究成果は実用炉設計法に有效に取り入れな ければならない。

（6）原子炉透蔽以外の放射線遮蔽設計等に対して も積極的に参加することが望ましい。

（7）他分野との交流を盛んにし，中間領域の研究 を積極的に行ならべきである。

その他委貣は多く積極的な意見を有している。これ らはまた機会を得て本「会誌上上あるいは原子力関係誌 上に怙いて述べることとして本報告を䅂る。

（1966年 8 月 8 日 受理）

(1) IAEA, Reactor Shielding, Tech. Rept. Ser. No. 34, (1964), Vienna.

（2）新藤満夫，古田悠，鹤尾昭，他：原子力工業，10 [12], 5 - 31 (1964).

(2a) 新藤满夫, 宮坂形一, 田中義久, 他: 同 上, 12[4], 5 33 (1966)

（3）古田 悠：本 誌，7[5]，260（1965）, 


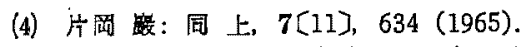

(5) 北爪光幸: 同上, 7[9]，496（1965）.

(6) 兵藤知典: 同上, 8[7], 371 (1966).

(7) G.W.GrodsteIN : X-ray Attenuation Coefficients from $10 \mathrm{keV}$ to $100 \mathrm{MeV}, N B S$ Circular 583. US Department of Commerce, (1957); R.T. MC GinNiES: ibid.. Suppl. NBS Circular 583, (1959).

(8) C.M.DAvisson: "Interaction of X-Radiation with Matter, in Alpha-, Bata-, Gamma-Rays Spectroscopy", ed. by K. SIEGBAHN, Vol. I, pp. 37 78 (1965), North-Holland Publ. Co., Amsterdam.

(9) H. Goldstein, J.E. Wirkins, Jr.: Calculations of the Penetration of Gamma Rays, NYO-3075 (1954).

(10) 鶴尾昭: 本誌, 6[9]，523(1964).

(11) B.T. PRICE, C.C. HoRTON, K.T. SPINNEY: "Radiation Shielding", (1959), Pergamon Press, London, Paris.

(12) T. RockweII, II, ed., "Reactor Shielding Design Manual", (1956), McGraw-Hill Book Co. Inc., New York.

(13) H. Goldstein: "Fundamental Aspects of Reactor Shielding", (1959), Addison-Wesley Publ. Co. Inc., U.S.A.

(4A) E.P. Blizard, L.S. ABbotT, ed.: "Reactor Handbook", 2nd ed., Vol. II-B, Shielding, (1962), Intersci. Publ., New York, London.

(15) D.L. BRODER, A.P. VESELKIN, YU.A. EgoRov, et al.: 原子炉遮蔽の問題点, (1963), ソビエト国立 原子科学工学図書出版，モスクワ（ロシア語，日本 語訳なし).

(16) 日本原子力船研究拹会: 遮蔽設計盗料集，(1963） 非売品.

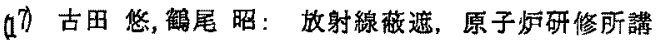
義テキストII，JAERI-Memo 1363, 79〜203 (1964), 非売品.

(18) T. JAEGER: "Grundzüge der Strahlexshutztechnik", (1960), Springer-Verlag, Berlin.

(19) 兵藤知典：放射線遮蔽入門，(1966)，産業図菁.

20) 原研東海研速蔽研究望備室：Status Report of Shielding Investigation in Japan, JAERI 4029, （1964），引用文埆1, pp. 37 56.

(21) 宮坂酸一: 日本の速蔽研究の問題点, 原子力工業, $10[12], 28$ (1964).

(22)石川寬, 朝网卓見, 笹倉 浩: JRR-3(国産 1 号哣) 設計計算, JAERI-1002，(1960).

(23) 日本原子力船研究拹会：原子炻速敵計算コードに 関する研究，(1961), 非壳品.

24) 同上: 原子力施設の遮敕計算(コード化)に関す

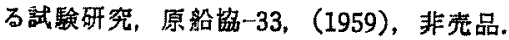

(25) 同 上：原子力船の遮蔽計算コードに関する試駼 研究，原船劦-45，(1961)，非艺品.

(26) 同 上：遮蔽設計資料集附録諸関数表，原船㙝 $-42-$ I. (1963), 非芜品.
27) 同上: 舶用遮蔽研究用スイミングプール型原子 炉の実験方法扣上び実驗装置についての調查研究， 原船協-27,（1962）, 非完品.

(28)望月博治, 田中義久, 他: 本 誌, 4[7], 448 (1962).

(29) 同 上: 同 上.4[10], 703 (1962).

(50) Y. Furuta, A. Tsuruo, S. Miyasaka, et al. Nucl. Sci. Eng., 25, 85 (1966).

(31) 金森善彦, 横田敏明, 曹里便：三井造船技報, No. 45, 20 (1964).

B2 宮坂黢一, 鹤尾 昭: 本会「第 5 回焙物理-第 3 回炉 工学合同分科会」予稿集，p. 66 (1965).

(33) 梅田晸, 兵藤知典: 同上. p. 68 .

(34)西嵒安,播磨昼子:同上，本会「昭和 40 年年会」要 旨集, p.41 (1965).

(35) 梅田 政: 本 誌, 7[9], 480（1965).

B6)鶴尾 昭：第 2 回原子力コード発表会予稿集, p. 166 176 (1965. 10)

(3) I. Kataoka, K. TakeUchI: J.Nucl. Sci. Technol., 2[1], 30 (1965).

38) I. KataOKa, K. TAKeUchI: Paper of Ship Research Inst., No. 6, (1965).

(39) 片网崖,竹内清: 船舶技研報告, 2, 297 (1965).

(40) 鶴尾 昭: 本誌，6[2]，91 (1964).

(41) I. UMEdA:J. Nucl. Sci. Technol., 1[2], 37(1964).

(42) 北爪光幸: 本 誌, 7[9]，496（1965）。

（43) 清水彰直, 水田 宏: 本会「昭和41年年会」要旨集， p. 205, (1966).

(44) T. Hyodo: Nucl. Sci. Eng., 12, 178 (1962).

(45) H. Fujita, K. Kobay ashi, T. HYODO: ibid., 19, 437 (1964).

(46)松本高明，水上維一，兵踩知典：本会「昭和39年年 会」予稿集，p.286 (1964)，

(47) 中田正也: 非破填険宵, 10, 263 (1962).

(48)中田正也，布施卓嘉，竹内清：運研報告，11，561 (1962).

(49) A. Shimizu, H. Mizuta: J. Nucl. Sci. Technol., 3[ 2], 57 (1966).

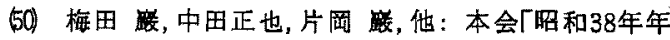
会」要旨集, p.188（1963），

(51) 八巻秀雄, 福島 稞,他：本会「昭和39年年会」要旨 集, p. 291 （1964）；「40年年会」要旨集, p. 42 (1965); $\lceil 41$ 年年会」要旨集, ’p.207 (1966).

52 同上:本会「炡物理·师工学分科会」予稿集, p. 87 88(1964); p. 64 65 (1965).

53) 川本節男，山田教，他：本会「昭和40年年会」要旨 集. p. 43 (1965).

(54) 同 上：本会「第 4 回炉物理·第 2 回滆工学合同分 科会」要旨集，p.86 (1964).

55)田中檥久，他：本会「昭和39年年会」要旨集， p. 297 〜298 (1964).

(50) 片凧蒜, 竹内清: 本会「昭和 40 年年会」要旨集, p. 39 (1965).

57) 北爪光幸，岛村 光，森 晃一: 同上, p.39.

58) 兵藤知典, 晁村 強: 本 誌, 3[4], 284 (1961).

59)田中䣡久，東原義治：本会「昭和39年年会」要旨集, 
p. 299 230（1964）；「昭和40年年会」要旨集， p.45 $\sim 47$, 「合同分科会」予稿集， p. 67 (1964).

(60)八巻秀雄, 福島 滦, 内田俊介: 本会「昭和41年年会」 要旨集, p.206 (1966).

(61) 浅田常三郎, 菊地理一, 野垣内武志, 他: 本誌, 2 [5], 245 (1960).

(62) A. Tsuruo, M. SHINDo, M. Kawabata: $J$. Nucl. Sci. Technol., 2[4], 121 (1965).

(63) ibid., 2[9],325 (1965).

(64) A. TSURo: ibid, 2[10], 406 (1965).

(65) H. Kakmoto, T. Saigusa, S. ShimizU: Bull. Inst. Chem., Kyoto Univ., 43, 22 (1965).

60) K. TAMURA, Y. KANAMORI, Y. FURUTA: Japan. J. Appl, Phys., 3, 232 (1965).

(67) 望月博治，田中義久: 原子力工業, 9[9], 54(1963).

(68) T. Hyodo, F. Makino: Mem. Faculty Eng., Kyoto Univ., 24, 291 (1962).

(69) 石松健二: 本 誌, 4[1], 24 (1962).

(70) 水上紶一, 兵藤知典: 旷刷中, (1966).
(71) Y. Furuta, S. Kinbara: Rev. Sci. Instr.,37; 176 (1966).

(72) H. ŌNo, A. Tsuruo: J. Nucl. Sci. Technol., 2[6], 229 (1965).

(73) A. Tsuruo: ibid., 2[7], 261 (1965).

(74) 田上㠇, 北爪光幸：本 誌，8[1]，12（1966）。

(75) 片岡筇, 金井務: 原子力船遮蔽コード，遮蔽研 究專門委員会資料， $S R C-1063 ，(1965)$.

76. 中田正也：遮蔽研究専閏委員会資料，SRC-1064, (1965).

(77) 日本造船研究協会: 原子力船第 1 船遮蔽效果磪琵 実鈳実施方案，(1965).

(78) I. UMEDA, T. HYODO: Nucl. Structural Eng., 2, 335 (1965).

(79)矢岛 明,市島季恭，上原由男，他：本会「昭和 40 年 年会」要旨集, p.210 (1966).

(80)峄村光: 同上, p. 48 (1965).

81) 北爪光幸：同上, p.49 (1965),

\section{功本誌投稿の手引约}

○一般投稿は研究論文・資料を原則とし, 必ず 会員の資格を要する。

○内容汢オリシナルるのに限り，暫く刷上り 6 頁以内（超過の場合には超過分 1 頁当り実費 約4,000円著者負担)とする。和文は「会誌」に， 欧文は Journal に揭载される。欧文の場合は修 文・添削にとく炕充分な考㦄を要する。

○揭载範囲は，原子力研究に関連する凡ゆる部 門を含め，とくに限定しない。

○赤筆にあたっては投樆規程に従い，所定の原 稿用紙を使用する(欧文は適宜に厚手のタイプ 用紙に 2 段送り，1枚約 25 行にタイプする。）和 ・欧文とも所定の原稿表紙を添付する。図面は そのまま製版できるよう必ず量入れトレースす る。

○投稿希望は事務局八連絡すれば，原熇用紙 (30枚緅 1 部100円T別)，投稿規程が送付される。

○和・欧文を問わず表題・抄録・所属機関名など を和・英両文で適磪に整いて源付する。

○別に校切り日は設计ない。原稿受理炊第厂受
理通知」を本人送る。原稿は当該分野担当の

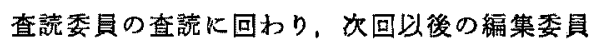
会において操否を憲議する。宣読通過およで揭 载巻号甠決定次第通知される。

○論文は查珫通過後受理順に揭载される。

(揭载まて欧文䄪 $1 \sim 2$ 力月，和文約 $4 \sim 5$ ヶ月）

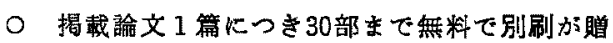
られる(30部以上希望の時は，1 部につき,100部 まで標染 4 頁以内50円，5～8頁60円の実費負担)。

○ 查珫·審議の結果, 内容·文章の短濰・修正，ま たは図面トレースの書直しを要求されたり，時 には揭載を遠虑いただ場合があるので，予め ご了承願いたい。

特に欧文の修文・添削についてはすべて著者 負担とする。(和訳を要求される場合るむる)

○返却原稿は 6 力月以内に再提出なき場合は撒 回とみなされる。

○ショートノート・談話室の各欄は，随時，随意 に気軽なご笴稿を笅迎する。

○その他, 詳細は事務局へ捄い合わせ下さい。 